\title{
Model of end stage liver disease (MELD) score greater than 23 predicts length of stay in the ICU but not mortality in liver transplant recipients
}

\author{
Christian E Oberkofler ${ }^{+1}$, Philipp Dutkowski ${ }^{+1}$, Reto Stocker ${ }^{2}$, Reto A Schuepbach², John F Stover2, Pierre- \\ Alain Clavien ${ }^{1}$ and Markus Béchir*2
}

\begin{abstract}
Introduction: The impact of model of end stage liver disease (MELD) score on postoperative morbidity and mortality is still elusive, especially for high MELD. There are reports of poorer patient outcome in transplant candidates with high MELD score, others though report no influence of MELD score on outcome and survival.

Methods: We retrospectively analyzed data of 144 consecutive liver transplant recipients over a 72 -month period in our transplant unit, from January 2003 until December 2008 and performed uni- and multivariate analysis for morbidity and mortality, in particular to define the influence of MELD to these parameters.

Results: This study identified MELD score greater than 23 as an independent risk factor of morbidity represented by intensive care unit (ICU) stay longer than 10 days (odds ratio 7.0) but in contrast had no negative impact on mortality. Furthermore, we identified transfusion of more than 7 units of red blood cells as independent risk factor for mortality (hazard ratio 7.6) and for prolonged ICU stay (odds ratio [OR] 7.8) together with transfusion of more than 10 units of fresh frozen plasma (OR 11.6). Postoperative renal failure is a strong predictor of morbidity (OR 7.9) and postoperative renal replacement therapy was highly associated with increased mortality (hazard ratio 6.8), as was hepato renal syndrome prior to transplantation (hazard ratio 13.2).
\end{abstract}

Conclusions: This study identified MELD score greater than 23 as an independent risk factor of morbidity represented by ICU stay longer than 10 days but in contrast had no negative impact on mortality. This finding supports the transplantation of patients with high MELD score but only with knowledge of increased morbidity.

\section{Introduction}

Liver transplantation is still a complex and cost-intensive procedure [1] and the results are influenced by many interrelated factors. As liver transplantation has become a universally accepted treatment for end-stage liver disease, the number of patients accumulating on the waiting list has gradually outweighed the scarce resources of available organs. Fair allocation of donor livers to patients with end-stage liver disease is a difficult task. The USA and Europe used prioritization systems based on waiting time and on the parameters of the Child-Turcotte-Pugh

* Correspondence: markus.bechir@usz.ch

2 Surgical Intensive Care Unit, University Hospital of Zurich, Raemistrasse 100,

Zürich 8091, Switzerland

† Contributed equally

Full list of author information is available at the end of the article score [2]. Since February 2002, the United Network for Organ Sharing introduced a new allocation policy for cadaveric liver transplants, based on the model for endstage liver disease (MELD) score [3]. This new policy stratifies the patients based on their risk of death while on the waiting list [4]. The impact of MELD score on postoperative mortality remains elusive. There are reports of reduced survival in groups with high MELD scores [5,6], but also reports of no influence of MELD score on survival $[7,8]$.

Furthermore, the unique pathophysiology of end-stage liver disease (ESLD) has important implications on critical care treatment after transplantation [9]. Although liver transplantation has been the sole treatment of patients with ESLD for over 20 years, only limited data 
are available addressing the intensive care management and complications of this patient population $[10,11]$.

The current challenge is to optimize outcome with limited resources, because liver transplantation remains financially expensive with incremental costs when postoperative complications occur. Therefore, it is essential to identify and modify risk factors to improve postoperative ICU management.

In this study we addressed the question of whether MELD score affects postoperative morbidity, represented by an increased length of stay in the ICU and mortality in patients after liver transplantation. Furthermore, the study was undertaken to determine the major ICU problems in such patients and to outline and predict major clinical risk factors regarding length of stay in the ICU and mortality.

Therefore, data from all consecutive liver transplants performed in our institution over six years, from 1 January 2003 to 31 December 2008, were analyzed.

\section{Materials and methods}

We included in the study a total of 144 consecutive patients who underwent liver transplantation between 1 January, 2003 and 31 December, 2008 in our transplant center. Five of these patients underwent seven retransplantations. Two of them underwent retransplantation twice and three patients only once, and two cases out of this seven were electively listed and five patients were high urgent listed. Thus, we included data of 151 liver transplantations in 144 patients over six years with a median follow up of 27.0 months into our study.

Patients were transplanted according to the MELD score, which is based on recipient kidney function, coagulation time and serum bilirubin, and ranges from 7 to 40. This score is a reliable parameter to predict mortality of liver transplant candidates on the waiting list [12]. In order to prevent discrimination of patients on the waiting list with a hepatic tumor or a metabolic and cholestatic disease, those patients received exceptional points, resulting in higher (corrected) MELD scores than the calculated laboratory (uncorrected) MELD would be [13]. Following approval by the local ethics committee, all patients gave written informed consent before transplantation for postoperative data analysis.

\section{Inclusion/exclusion criteria}

We included all adult ( $>16$ years of age) liver transplant recipients from January 2003 until December 2008 who were electively or high urgently listed. The only exclusion criteria were living related liver transplant recipients. One patient, who was retransplanted twice (electively listed) during this period was excluded from analysis, because the initial transplantation was before the study period.

\section{Pretransplant recipient data}

We defined extended donor criteria (marginal grafts) as either age 65 years or older or cold ischemia time of 720 minutes or longer or biopsy-proven steatosis (micro- or macrovascular in $\geq 60 \%$ of hepatocytes or $\geq 30 \%$ macrovascular steatosis) $[14,15]$.

As baseline characteristics we analyzed age, gender, height, weight, body mass index, creatinine, hematocrit and platelet count. Creatinine values of the patients with renal replacement therapy (RRT) prior to transplantation were excluded from the calculation. For analysis the last available values directly before transplantation were included. Furthermore, the following clinical data were collected: underlying liver disease, Child-Turcotte-Pugh classification, MELD score uncorrected and corrected for hepatocellular carcinoma according to the regulation of the government [13], incidence of hepatorenal syndrome directly before transplantation (according to the definition described by Arroyo and colleagues [16] and Salerno and colleagues [17]), and diabetes mellitus, electively or high urgent listing, pretransplant location (home, normal hospital ward or ICU) and finally the need for pretransplant RRT.

\section{Operative data}

All patients were transplanted without veno-venous bypass, as described by McCormack and colleagues [18]. Management of coagulation and transfusion practice was performed according to the internal guidelines. Patient data were collected in respect to operating time, estimated intraoperative blood loss, transfusion of red blood cells (RBC), fresh frozen plasma (FFP) or platelets and intraoperative application of fibrinogen.

\section{ICU data}

The following data were collected: length of stay in the ICU, incidence of readmission to the ICU, readmission cause, serum creatinine peak level, incidence of renal failure assessed by the RIFLE (risk, injury, failure, loss, endstage of kidney disease) criteria, incidence of RRT, incidence of sepsis, incidence of pulmonary failure (acute respiratory distress syndrome (ARDS), pneumonia with consecutive reintubations), ventilation days, serum peak values of bilirubin, alkaline phosphatase, alanine aminotransferase (ALT) and aspartate aminotransferase (AST); incidence of primary graft nonfunction and retransplantation, incidence of rejection on the ICU and reoperations during the ICU stay, and the incidence of acute coronary syndrome. In the case of four primary graft nonfunctions in the ICU with a following four consecutive emergency retransplantations, we considered those four retransplantations as ICU complications and analyzed these patients as four ICU cases. Furthermore, we considered three electively listed retransplantations as 
three additional cases and therefore calculated the ICU parameters from 147 transplantation cases out of 144 patients. The graft specific parameters, that is peaks of bilirubin, alkaline phosphatase, ALT and AST, were analyzed from all 151 transplanted grafts.

\section{Analysing protocol Influence of MELD}

The influence of patients MELD score on postoperative mortality and length of stay in the ICU longer than 10 days (morbidity) was univariately and multivariately analyzed in 128 electively listed and transplanted patients. High urgent listed patients were not included in these analysis because of another allocation system according to the Clichy criteria [19].

\section{Graft survival, mortality}

We analyzed data in respect to graft survival after one year, three years and five years and patient's survival was calculated for one year, three years and five years, respectively. Furthermore, the ICU and hospital mortalities (mortality during the hospital period of the transplantation in our center without transfers to other hospitals) were analyzed. For graft survival we analysed the data of all 151 transplantations and all the 144 patients were included in the survival analysis.

\section{Identifying risk factors}

We performed a Cox proportional hazard model to identify risk factors for mortality of liver transplant recipients. Through multiple logistic regression analysis we identified predictive factors for ICU length of stay of more than 10 days.

\section{Statistical analysis}

MELD influence on mortality and length of stay in the ICU of more than 10 days was univariately performed with an unpaired t-test. For multivariate analysis we used the method of multiple logistic regression to identify risk factors for length of stay in the ICU and a Cox proportional hazard model to identify independent risk factors for mortality. Calculation of mortality and graft survival was performed by Kaplan Meier analysis. We calculated the baseline characteristics, operative parameters, incidence of ICU complications, rejections and reoperation incidence as the relative and absolute numbers. Data are expressed as mean \pm standard deviation; different data expression is stated in the text. All calculations were performed with Statview 4.5 (abacus concepts, Berkeley, CA, USA). Statistical significance was accepted with $P<0.05$ (two-sided tests).

\section{Results}

\section{How were the pretransplant baseline conditions?}

The baseline characteristics of the recipients are shown in Table 1. The underlying liver diseases of the 144 patients are presented in Table 2. The incidence of hepa-
Table 1: Baseline characteristics ( $n=144$ patients)

\begin{tabular}{lc}
\hline Men & $110(76.4 \%)$ \\
Women & $34(23.6 \%)$ \\
\hline Weight $(\mathrm{kg})$ & $77.5 \pm 16.1(43-136)$ \\
Height $(\mathrm{m})$ & $1.73 \pm 0.10(1.50-1.95)$ \\
$\mathrm{BMl}\left(\mathrm{kg} / \mathrm{m}^{2}\right)$ & $25.8 \pm 4.3(16.0-42.9)$ \\
\hline Creatinine $(\mu \mathrm{mol} / \mathrm{l})$ & $102 \pm 56(40-509)$ \\
Hematocrit $(\%)$ & $32.4 \pm 6.6(15.3-49.6)$ \\
Platelets $\left(10^{3} / \mu \mathrm{l}\right)$ & $104 \pm 60(22-285)$ \\
\hline $\begin{array}{l}\text { Data expressed as mean } \pm \text { standard deviation }(\mathrm{range}) . \mathrm{BMI}, \text { body } \\
\text { mass index. }\end{array}$
\end{tabular}

torenal syndrome and diabetes mellitus was 29 patients $(20.1 \%)$ and 26 patients (18.1\%), respectively. The mean MELD score of these 128 patients was corrected $19.5 \pm$ 7.1 (median 19, range 8 to 40 ) and uncorrected $15.8 \pm 8.6$ (median 15, range 6 to 40), respectively. Sixteen out of 144 patients $(11.1 \%)$ or 21 out of 151 transplantations (13.9\%) (inclusive of four retransplantations) were high urgent listed and transplanted because of acute liver failure or primary graft nonfunction, respectively. The location of the patients directly before transplantation was $106(70.2 \%)$ at home, $18(11.9 \%)$ on a normal ward and 27 (17.9\%) on the ICU. The incidence of pretransplant RRT was 7 out of 144 patients (4.8\%).

The mean age of donors was $48.6 \pm 17.1$ years and the cold ischemia time was $539 \pm 166$ minutes. According to the chosen criteria for extended donor grafts 57 out of $151(37.7 \%)$ marginal donor grafts used in our study population showed at least one of the defining criteria.

\section{How was the intraoperative management?}

The mean operation time for the 151 transplantations was $391 \pm 90$ minutes (median 370, range 280 to 705 ). The estimated blood loss during the operating procedure was 2,559 $\pm 2,860 \mathrm{ml}$ (median 1,300, range 200 to 15,000 ). Transfusion requirements during transplantation were $6.2 \pm 8.1$ units of RBC (median 4, range 0 to 47), $14.2 \pm$ 12.9 units of FFP (median 12, range 0 to 77 ), $1.7 \pm 2.9$ units of platelets (median 1, range 0 to 18) and fibrinogen $3.2 \pm 5.1 \mathrm{~g}$ (median 0 , range 0 to 22 ).

In a total of $117(81.8 \%)$ transplantations RBC were transfused, in 133 (86.9\%) FFP and in 71 (50.7\%) platelets were given. No transfusion of RBC, FFP or platelets was achieved only in seven (4.6\%) transplantations. Fibrinogen was administered in 76 (49.6\%) transplantations.

\section{Did MELD affect postoperative course?}

The analysis of the 147 ICU cases showed a mean initial ICU length of stay of $8.8 \pm 13.6$ days (median 4, range 2 to $94)$, a readmission rate of $34(22.8 \%)$, whereas 7 patients 
Table 2: Underlying liver diseases ( $n=144$ patients)

\begin{tabular}{|c|c|}
\hline HCV liver cirrhoses overall & $54(37.5 \%)$ \\
\hline $\mathrm{HCV}$ liver cirrhoses + HCC & 20 (13.9\%) \\
\hline HBV liver cirrhoses overall & $16(11.1 \%)$ \\
\hline HBV liver cirrhoses $+\mathrm{HCC}$ & $7(4.9 \%)$ \\
\hline HCC overall & $41(28.5)$ \\
\hline $\begin{array}{l}\text { Alcoholic liver cirrhosis } \\
\text { overall }\end{array}$ & $24(16.7 \%)$ \\
\hline $\begin{array}{l}\text { Alcoholic liver cirrhosis + } \\
\text { HCC }\end{array}$ & $1(0.7 \%)$ \\
\hline Alcoholic liver cirrhosis + HBV & $1(0.7 \%)$ \\
\hline Acute liver failure & $12(8.3 \%)$ \\
\hline PSC & $5(3.5 \%)$ \\
\hline PBC & $4(2.8 \%)$ \\
\hline Morbus Wilson & $4(2.8 \%)$ \\
\hline Cryptogenic liver cirrhosis & $2(1.4 \%)$ \\
\hline Amyloidosis & $3(2.1 \%)$ \\
\hline Budd chiari syndrome & $2(1.4 \%)$ \\
\hline $\begin{array}{l}\text { Alpha-1-antitrypsin } \\
\text { deficiency }\end{array}$ & $1(0.7 \%)$ \\
\hline AlH liver cirrhosis & $1(0.7 \%)$ \\
\hline Polycyclic liver disease & $1(0.7 \%)$ \\
\hline Hyperoxalurie & $1(0.7 \%)$ \\
\hline $\begin{array}{l}\text { Vanishing bile duct } \\
\text { syndrome }\end{array}$ & $1(0.7 \%)$ \\
\hline M. Osler & $1(0.7 \%)$ \\
\hline
\end{tabular}

were readmitted twice and one patient 4 times. The mean readmission length of stay was $2.0 \pm 6.5$ days (median 0 , range 0 to 50) and in turn the overall length of stay in the ICU was $11.3 \pm 16.1$ days (median 5 , range 2 to 96 ). The serum creatinine peak level in the ICU was $174 \pm 91$ $\mu \mathrm{mol} / \mathrm{l}$ (median 155, range 64 to 429 ). The incidence of renal failure according to the RIFLE criteria in the 137 ICU cases without pretransplant RRT was: class 1 (risk) 26 (19.0\%), class 2 (injury) 26 (19.0\%), class 3 (failure) 34 (24.8\%) and class 4 (loss) 9 (6.6\%), with overall 95 (69.3\%) patients presented with renal failure in different stages.

RRT was necessary in $32(21.8 \%)$ of the transplanted patients at the initial ICU stay and in 33 patients (22.4\%) over all ICU days together, inclusive of readmission time. Ventilation days during the ICU stay were $4.7 \pm 10.5$ days (median 2, range 1 to 80 ). The ICU complications were: sepsis in 16 patients (10.8\%), respiratory failure (ARDS, pneumonia, reintubation) in 15 patients $(10.2 \%)$, primary graft nonfunction and retransplantation in 4 patients (2.7\%), rejection during ICU in 13 patients $(8.8 \%)$ after a median of 10 days (range 4 to 20), reoperations during the ICU stay in 29 patients (19.7\%) whereas 21 (14.3\%) patients had 1 reoperation, $2(1.4 \%)$ patients had 2 reoperations, $3(2.0 \%)$ patients had 3, $2(1.4 \%)$ patients 4 and 1 patient had 10 reoperations. Taken together the 147 transplant recipients underwent 52 reoperations during their ICU stay. One patient $(0.7 \%)$ underwent percutaneous coronary intervention after the occurrence of acute coronary syndrome (Figure 1). After transplantation, the serum peak levels of bilirubin was $136 \pm 116 \mu \mathrm{mol} / \mathrm{l}$, alkaline phosphatase was $170 \pm 136 \mathrm{U} / \mathrm{l}$, ALT was $1401 \pm 1436$ $\mathrm{U} / \mathrm{l}$ and AST was $2199 \pm 2734 \mathrm{U} / \mathrm{l}$. The causes for readmission are shown in Table 3.

\section{How was the mortality rate?}

The ICU mortality was $3.5 \%$ (5 of 144 patients) and the hospital mortality was $5.6 \%$ (8 of 144 patients). Cumulative graft survival was $86.5 \%$ after one year, $79.3 \%$ after three years and $67.9 \%$ after five years and the cumulative patients survival was $89.5 \%$ after one year, $84.1 \%$ after three years and $74.1 \%$ after five years, respectively (Figure 2).

\section{Did MELD affect morbidity and mortality?}

MELD score corrected was significantly increased in the patients, which stayed longer than 10 days in the ICU $(22.3 \pm 7.6$ vs. $18.8 \pm 7.2, P=0.015)$, but had no influence on mortality (Figure 3 ). The odds ratio for longer $(>10$ days) ICU stay was 7.0 (confidence interval: 1.7 to $28.4, P$ $=0.007)$.

\section{What are the risk factors for mortality?}

The Cox proportional hazard model for mortality identified sepsis $(P=0.011)$, postoperative RRT on ICU $(P=$ 
Table 3: Readmission causes ( $n=29 ; 19.7 \%$ )

\begin{tabular}{ll}
\hline Typ & Number \\
\hline Neurological & $2(1.4 \%)$ \\
$\begin{array}{l}\text { Reanimation after cardiac } \\
\text { arrest }\end{array}$ & $1(0.7 \%)$ \\
Respiratory failure & $3(2.1 \%)$ \\
Renal failure & $4(2.8 \%)$ \\
Liver failure & $4(2.8 \%)$ \\
Gastrointestinal bleeding & $2(1.4 \%)$ \\
Other abdominal & $8(5.6 \%)$ \\
pathologies & $2(1.4 \%)$ \\
Infection/sepsis & $3(2.1 \%)$ \\
Others & \\
\hline
\end{tabular}

$0.002)$, transfusion of more than 7 units of $\mathrm{RBC}(P=$ $0.045)$ and hepatorenal syndrome before transplantation $(P=0.016)$ as independent risk factors for mortality. Transfusion of more than 10 units of FFP, gender, use of marginal grafts, age, pretransplant diabetes mellitus, or postoperative bilirubin peak level, did not affect mortality (Table 4).

\section{What are the risk factors for morbidity?}

The multiple logistic regression analysis of predictive factors for ICU length of stay of more than 10 days identified use of marginal grafts $(P=0.022)$, development or renal failure of more than RIFLE class $2(P=0.006)$, transfusion of more than 10 units of FFP $(P=0.034)$, respiratory failure $(P=0.009)$, MELD score corrected above $23(P=$ $0.007)$, transfusion of more than 7 units of $\mathrm{RBC}(P=$ $0.032)$ and sepsis $(P=0.046)$ as independent risk factors. Age, gender, preoperative incidence of diabetes mellitus, directly pretransplantation ICU admission (transplanta- tion from the ICU), postoperative bilirubin serum peak level were no predictors of length of stay in the ICU (Table 5).

\section{Discussion}

Currently allocation of liver organs through the MELD system and the impact on patient outcome is a hot debate. Data on the impact of preoperatively assessed MELD score on the morbidity and mortality of postoperative recipients are only few. This study correlated morbidity, but not mortality with the MELD score in patients after liver transplantation in uni- and multivariate analyses and demonstrated a MELD score above 23 to be an independent risk factor for an ICU stay longer than 10 days (odds ratio 7.0). Siniscalchi and colleagues reported a correlation of MELD score and postoperative complications in 242 liver transplants [20]. Interestingly, the MELD scores in that study were similar to our findings ( 22.8 vs. 22.3 in our study in the high morbidity group and 17.6 vs. 18.8 in the low morbidity group). Another study associated increased length of stay in the ICU in association with high MELD score above 30 [7], but failed to find a difference in mortality. Only in patients exceeding a MELD score of 36 , mortality seems to be predicted by MELD as reported from Saab and colleagues [21]. In our population, four patients showed MELD score above 35 , three of them died in the postoperative course. In contrast, a study of 340 transplanted patients showed no difference in early death in respect to the MELD score [8]. Several other publications from the USA have also document that MELD score cannot predict survival after liver transplantation [22-24]. Nevertheless, the question of whether very high MELD scores affect mortality remains elusive. Taken together, despite no clear correlation of MELD score and postoperative mortality, there is strong

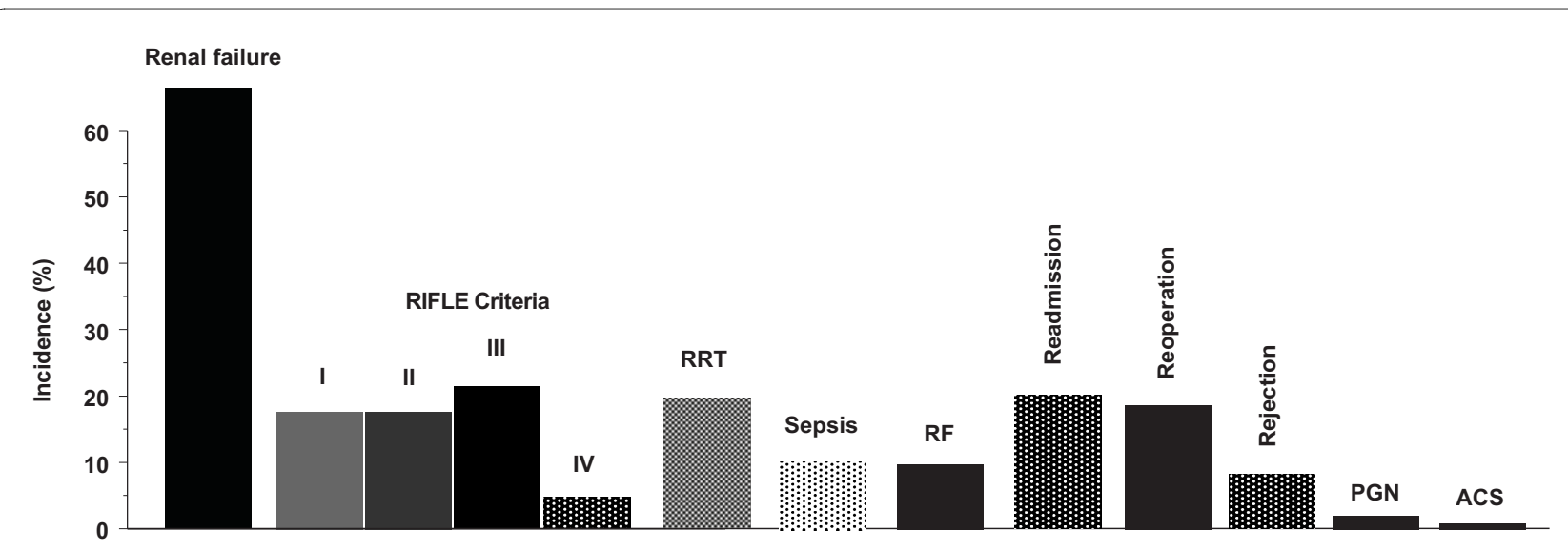

Figure 1 ICU complications of the 147 ICU cases. ACS, acute coronary syndrome; PGN, primary graft nonfunction; RF, respiratory failure; RRT, renal replacement therapy. 


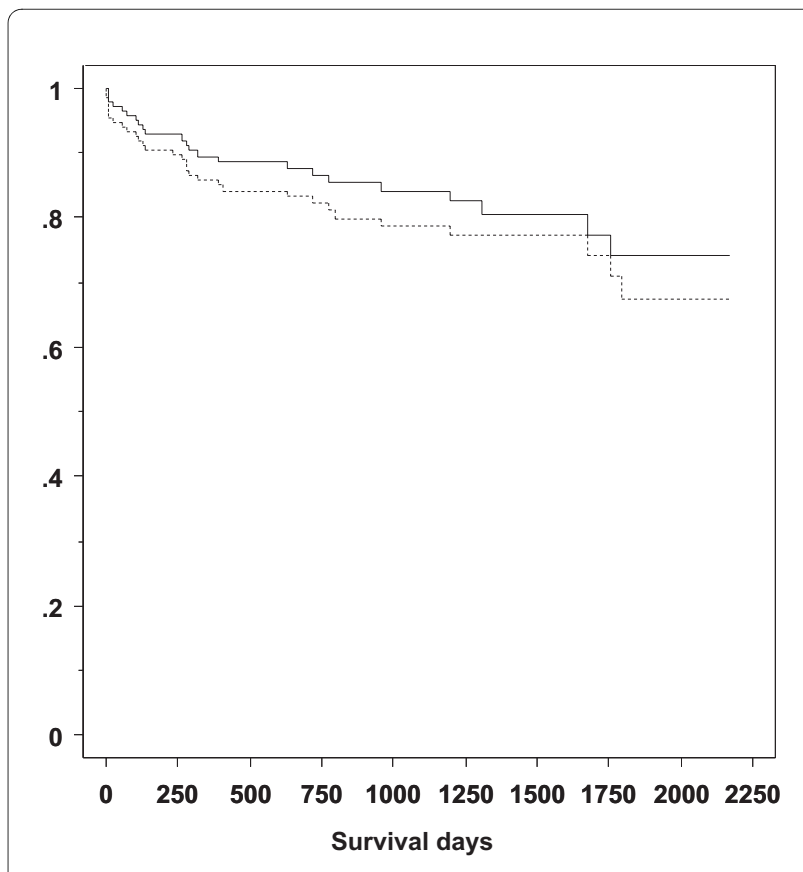

Figure 2 Kaplan Meier analysis of cumulative graft survival (dashed line) and cumulative patient's survival (full line). Graph shows results for 144 patients and 151 grafts.

evidence of MELD influencing postoperative morbidity and in turn cost [25].

Another finding of this study was a high incidence of postoperative renal failure and subsequently need for RRT. Cox proportional hazard model revealed RRT in the ICU as an independent risk factor for mortality. RRT in our population was necessary in $21.8 \%$ during ICU stay. Other studies reported an incidence ranging from 3\% to $20 \%$ [26-28] depending on the severity of preexisting renal conditions. Our study population included seven cases of pretransplant RRT already in need of RRT. This fact probably contributed to a higher incidence of renal failure when compared with those studies.

Apart from higher postoperative costs, renal failure and subsequent need for RRT is associated with increased mortality in ICU patients in general [29] and in particular in liver transplant recipients, varying from $27 \%$ to $67 \%$ depending on the comorbidities [30-33]. There is strong evidence that even mild renal failure after transplantation might lead to longer hospital stay, more infections and increased overall mortality [33-35].

In our study population, 95 (67.9\%) patients presented with renal failure at different stages according to the RIFLE criteria. Planinsic and Lebowitz observed renal failure in more than $80 \%$ of cases during the first 48 hours after surgery for liver transplantation. Mortality was extremely high in up to $50 \%$ of liver transplant recipients with renal dysfunction at 30 days following surgery and, if hemodialysis was required, it could reach $60 \%$ [35]. The
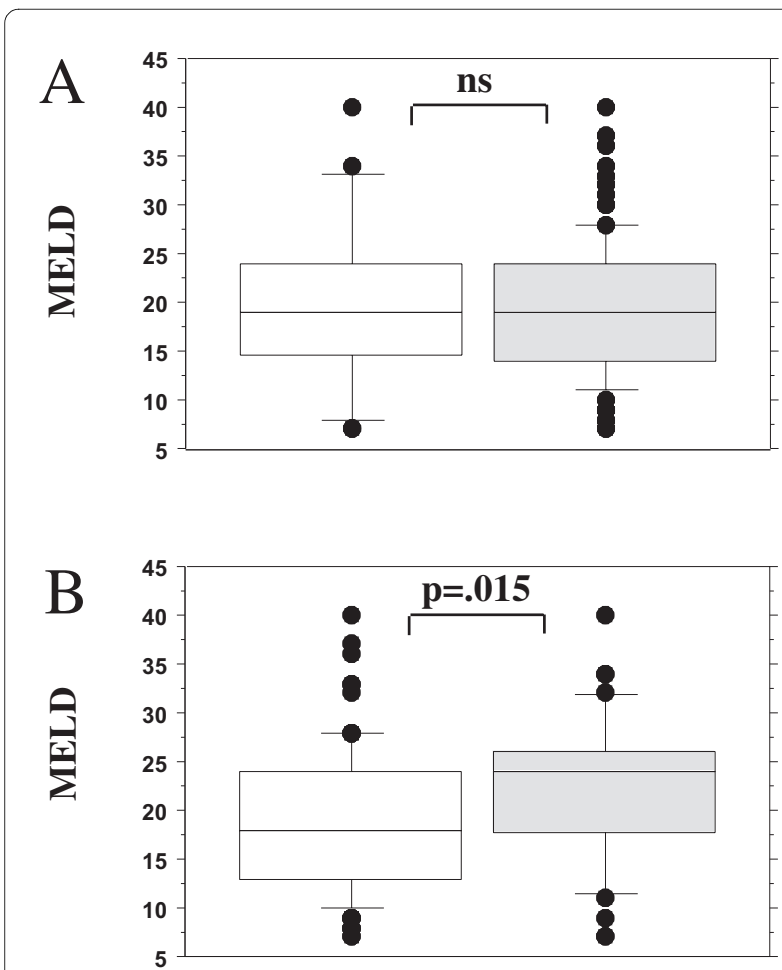

Figure 3 Influence of MELD score on (a) mortality and (b) length of stay in the ICU of more than $\mathbf{1 0}$ days. There was a significant higher model of end-stage liver disease (MELD) in the group, which stayed longer in the ICU (grey box). In contrast there was no difference in MELD in respect to mortality. (a) 24 no survivors vs. 104 survivors. (b) 35 with a long ICU stay versus 93 short time ICU patients. ns, not significant.

etiology of renal failure after liver transplantation is certainly multifactorial. Most reported risk factors are pretransplant renal dysfunction, low serum albumin, dysfunction of the liver graft, bacterial infections and reoperations [36].

Furthermore, the contribution of intraoperative stressors is not to be neglected: hypotension with or without hypovolemia, operation without veno-venous bypass $[37,38]$ and use of nephrotoxic agents as antibiotics or immunosuppressants may further contribute to progressive renal failure.

Interestingly in our study population among the patients in need of postoperative RRT, even patients with preoperative normal kidney function could be found, which underlines the impact of intra- and postoperative stressors on renal failure. The focus of postoperative management should lie on provisions to avoid renal failure and logically lower morbidity and mortality.

Looking at preoperative kidney function in our study population we found an incidence of hepatorenal syndrome of $20 \%$ with a hazard ratio of 13 , which corresponds to other studies [39-41]. Although liver transplantation can correct hepatorenal syndrome [42], 
Table 4: Cox proportional hazard model for mortality

\begin{tabular}{|c|c|c|c|}
\hline Parameter & $P$ value & Hazard ratio & Confidence interval \\
\hline Incidence of HRS pre TPL & 0.016 & 13.2 & $1.6-108.8$ \\
\hline Sepsis in ICU & 0.011 & 8.9 & $1.6-47.6$ \\
\hline Transfusion $>7$ RBC & 0.045 & 7.6 & $1.04-55.6$ \\
\hline Renal replacement therapy in ICU & 0.002 & 6.8 & $2.0-22.7$ \\
\hline Use of marginal grafts & 0.39 & 1.6 & $0.6-4.6$ \\
\hline Transfusion $>10 \mathrm{FFP}$ & 0.93 & 1.0 & $0.9-1.1$ \\
\hline Peak bilirubin serum level & 0.25 & 1.0 & $0.9-1.1$ \\
\hline Diabetes mellitus preoperative & 0.65 & 1.3 & $0.4-4.4$ \\
\hline MELD $>23$ & 0.26 & 1.1 & $0.9-1.3$ \\
\hline Gender & 0.56 & 1.4 & $0.4-4.9$ \\
\hline Age & 0.41 & 1.0 & $0.9-1.1$ \\
\hline
\end{tabular}

the time frame for recovery of renal function seems to be too long for RRT-free management. Often RRT is needed as a bridging therapy until the kidneys recover. In our study population, if duration of dialysis pretransplant was less than 30 days only $8 \%$ of patients still require hemodialysis 8 weeks after transplantation, which is somewhat in contrast to the study by Lo and colleagues, where $25 \%$ of the patients with hepatorenal syndrome require longterm RRT after transplantation [43]. Thus, hepatorenal syndrome is not always reversed, in particular when pretransplant RRT is necessary [44] and additional kidney transplantation becomes an option [40]. Hepatorenal syndrome prior to transplantation and RRT postoperatively are strong predictors for mortality in liver transplant recipients and the postoperative renal impairment leads to a prolonged ICU stay for these patients.

Allogeneic FFP and RBC transfusions are associated with well-known adverse effects, reflected by increased incidence in viral and bacterial infections, activation of inflammatory and coagulation pathways, and immunologic reactions [45-47]. In patients after liver transplantation, intraoperative transfusion of packed RBCs are associated with more complications $[48,49]$ and infections [50]. Our multivariate analysis revealed transfusion of more than 7 units of RBCs and transfusion of more than 10 units of FFP as independent risk factors for mortality and prolonged ICU stay. Other reports identified intraoperative transfusion as a risk factor for morbidity and mortality in liver transplant recipients $[39,50,51]$ and Massicotte and colleagues could demonstrate that a restrictive transfusion regime was associated with better outcome in liver transplantation recipients with an average MELD of 18 [49]. Thus, avoiding transfusion of RBC seems to be crucial to reduce postoperative morbidity and mortality.

In our group ICU mortality was $3.5 \%$ and the hospital mortality was $5.6 \%$. The hospital mortality is closely related to the hospital length of stay [52]. Our survival data are similar to other transplant programs [6-8] with a cumulative patient survival of $89.5 \%$ after one year, $84.1 \%$ after three years and $74.1 \%$ after five years, even though in our study population $38.4 \%$ of marginal donor grafts were transplanted. In our study population, the use of marginal liver grafts was associated with higher ICU length of stay, but did not lead to an increased overall mortality $[53,54]$ and is able to decrease wait list mortality.

Sepsis was also highly associated with prolonged ICU stay and increased mortality confirming the results of other studies $[55,56]$. It is still a leading cause of death $(20$ 
Table 5: Multiple logistic regression for ICU length of stay of more than 10 days

\begin{tabular}{|c|c|c|c|}
\hline Parameter & $P$ value & Odds ratio & Confidence interval \\
\hline Sepsis in ICU & 0.046 & 46.7 & $1.1-2038.1$ \\
\hline Respiratory failure & 0.009 & 18.7 & $2.1-166.1$ \\
\hline Transfusion of $>10 \mathrm{FFP}$ & 0.034 & 11.6 & $1.2-111.7$ \\
\hline Transfusion of $>7$ RBC & 0.032 & 7.8 & $1.2-50.5$ \\
\hline Renal failure $>$ RIFLE class 2 & 0.006 & 7.9 & $1.9-34.1$ \\
\hline MELD score corrected $>23$ & 0.007 & 7.0 & $1.7-28.4$ \\
\hline Use of marginal grafts & 0.022 & 5.1 & $2.3-500.0$ \\
\hline Gender & 0.54 & 1.0 & $0.9-1.1$ \\
\hline Age & 0.08 & 1.0 & $0.9-1.1$ \\
\hline $\begin{array}{l}\text { Diabetes mellitus } \\
\text { preoperative }\end{array}$ & 0.46 & 1.7 & $0.4-6.4$ \\
\hline $\begin{array}{l}\text { Transplantation directly from } \\
\text { the ICU }\end{array}$ & 0.63 & 1.6 & $0.2-10.5$ \\
\hline Peak bilirubin serum level & 0.45 & 1.0 & $0.9-1.1$ \\
\hline
\end{tabular}

to $50 \%$ in non-cardiac ICUs [57]. In our study population sepsis occurred in $10.8 \%$, that is, it was ranked fourth in the complication list after renal failure, readmissions and reoperations.

The gastrointestinal system might play a key role in the pathogenesis owing to a breakdown of intestinal barrier function. Gurusamy and colleagues concluded from their database review that the use of prebiotics and probiotics might be effectful in the prevention of sepsis [58]. However, our patients received no prebiotics or probiotics, but this might be a beneficial therapeutical option in the future. Most importantly these patients should be management according to the guidelines of the Survival Sepsis Campaign $[59,60]$.

\section{Conclusions}

This study identified MELD score above 23 as an independent risk factor of morbidity represented by ICU stay longer than 10 days but it did not clearly affect mortality. This finding supports the transplantation of patients with high MELD score at the cost of increased postoperative morbidity, in particular when it is seen in the light of reduced waiting list mortality. Furthermore, we identified transfusion of more than seven units of RBCs as an independent risk factor for mortality and for prolonged ICU stay. Postoperative renal failure and transfusion of more than 10 units of FFP are strong predictors of morbidity and postoperative RRT was highly associated with increased mortality, as was hepatorenal syndrome prior to transplantation.

\section{Key messages}

- High MELD scores greater than 23 did not affect mortality in liver transplant recipients.

- Sepsis, postoperative RRT on ICU, transfusion of more than seven units of RBC and hepatorenal syndrome before transplantation were strong predictors for mortality in liver transplant recipients.

- Transplantation of marginal grafts, development or renal failure greater than RIFLE class 2, transfusion of 
more than 10 units of FFP, respiratory failure, MELD score greater than 23, transfusion of more than seven units of RBC and sepsis are predictors for increased length of stay in the ICU.

\section{Abbreviations}

ALT: alanine aminotransferase; ARDS: acute respiratory distress syndrome; AST: aspartate aminotransferase; ESLD: end-stage liver disease; FFP: fresh frozen plasma; MELD: model of end-stage liver disease; RBC: red blood cells; RRT: renal replacement therapy.

\section{Competing interests}

The authors declare that they have no competing interests.

\section{Authors' contributions}

MB and CEO designed the study. CEO and PD performed the study. RS and JFS collected data. RAS analysed data. PAC and MB wrote the paper.

\section{Author Details}

1Department of Visceral- and Transplantation Surgery, University Hospital of Zurich, Raemistrasse 100, Zürich 8091, Switzerland and 2Surgical Intensive Care Unit, University Hospital of Zurich, Raemistrasse 100, Zürich 8091, Switzerland

Received: 16 February 2010 Revised: 30 April 2010

Accepted: 15 June 2010 Published: 15 June 2010

\section{References}

1. Sagmeister M, Mullhaupt B: Is living donor liver transplantation costeffective? J Hepatol 2005, 43:27-32.

2. Sachdev M, Hernandez JL, Sharma P, Douglas DD, Byrne T, Harrison ME, Mulligan D, Moss A, Reddy K, Vargas HE, Rakela J, Balan V: Liver transplantation in the MELD era: a single-center experience. Dig Dis Sci 2006, 51:1070-1078

3. Martin AP, Bartels M, Hauss J, Fangmann J: Overview of the MELD score and the UNOS adult liver allocation system. Transplant Proc 2007, 39:3169-3174

4. Ravaioli M, Grazi GL, Ballardini G, Cavrini G, Ercolani G, Cescon M, Zanello M, Cucchetti A, Tuci F, Del Gaudio M, Varotti G, Vetrone G, Trevisani F, Bolondi L, Pinna AD: Liver transplantation with the Meld system: a prospective study from a single European center. Am J Transplant 2006, 6:1572-1577.

5. Tsui TY, Scherer MN, Schnitzbauer AA, Schlitt HJ, Obed A: Adult living donor liver transplantation: body mass index and MELD score of recipients are independent risk factors for hospital mortality. Langenbecks Arch Surg 2009, 394:235-241.

6. Organ Procurement and Transplantation Network [http:// www.optn.org]

7. Ferraz-Neto BH, Zurstrassen MP, Hidalgo R, Meira-Filho SP, Rezende MB, Paes AT, Afonso RC: Analysis of liver transplantation outcome in patients with MELD Score $>$ or $=30$. Transplant Proc 2008, 40:797-799.

8. Santoyo J, Suarez M, Fernandez-Aguilar J, Perez Daga J, Sanchez-Perez B, Ramirez C, Aranda J, Rodriguez-Canete A, Gonzalez-Sanchez A: True impact of the indication of cirrhosis and the MELD on the results of liver transplantation. Transplant Proc 2006, 38:2462-2464.

9. Saner FH, Sotiropoulos GC, Radtke A, Fouzas I, Molmenti EP, Nadalin S, Paul A: Intensive care unit management of liver transplant patients: a formidable challenge for the intensivist. Transplant Proc 2008, 40:3206-3208

10. McGilvray ID, Greig PD: Critical care of the liver transplant patient: an update. Curr Opin Crit Care 2002, 8:178-182.

11. Saner F, Kavuk I, Lang H, Fruhauf NR, Paul A, Stavrou G, Malago M, Broelsch CE: Postoperative ICU management in liver transplant patients. Eur J Med Res 2003, 8:511-516.

12. Cholongitas E, Marelli L, Shusang V, Senzolo M, Rolles K, Patch D, Burroughs AK: A systematic review of the performance of the model for end-stage liver disease (MELD) in the setting of liver transplantation. Liver Transp/ 2006, 12:1049-1061.

13. Swiss National Foundation for organ donation and transplantation [http://www.Swisstransplant.org]
14. Adam R, Bismuth H, Diamond T, Ducot B, Morino M, Astarcioglu I, Johann M, Azoulay D, Chiche L, Bao YM, et al.: Effect of extended cold ischaemia with UW solution on graft function after liver transplantation. Lancet 1992, 340:1373-1376.

15. Merion RM, Goodrich NP, Feng S: How can we define expanded criteria for liver donors? J Hepatol 2006, 45:484-488,

16. Arroyo V, Gines P, Gerbes AL, Dudley FJ, Gentilini P, Laffi G, Reynolds TB, Ring-Larsen H, Scholmerich J: Definition and diagnostic criteria of refractory ascites and hepatorenal syndrome in cirrhosis. International Ascites Club. Hepatology 1996, 23:164-176.

17. Salerno F, Gerbes A, Gines P, Wong F, Arroyo V: Diagnosis, prevention and treatment of hepatorenal syndrome in cirrhosis. Gut 2007, 56:1310-1318.

18. McCormack L, Selzner M, Clavien P-A: The transplant operation. In Medical Care of Liver Transplantation Edited by: Killenberg P, Clavien P-A. Oxford, England: Blackwell Publishing; 2006:229-241.

19. Yantorno SE, Kremers WK, Ruf AE, Trentadue JJ, Podesta LG, Villamil FG: MELD is superior to King's college and Clichy's criteria to assess prognosis in fulminant hepatic failure. Liver Transp/ 2007, 13:822-828.

20. Siniscalchi A, Cucchetti A, Toccaceli L, Spiritoso R, Tommasoni E, Spedicato S, Dante A, Riganello L, Zanoni A, Cimatti M, Pierucci E, Bernardi E, Miklosova Z, Pinna AD, Faenza S: Pretransplant model for end-stage liver disease score as a predictor of postoperative complications after liver transplantation. Transplant Proc 2009, 41:1240-1242.

21. Saab S, Wang V, Ibrahim AB, Durazo F, Han S, Farmer DG, Yersiz H, Morrisey M, Goldstein LI, Ghobrial RM, Busuttil RW: MELD score predicts 1-year patient survival post-orthotopic liver transplantation. Liver Transp/ 2003, 9:473-476.

22. Bazarah SM, Peltekian KM, McAlister VC, Bitter-Suermann H, MacDonald AS: Utility of MELD and Child-Turcotte-Pugh scores and the Canadian waitlisting algorithm in predicting short-term survival after liver transplant. Clin Invest Med 2004, 27:162-167.

23. Kremers WK, van IM, Kim WR, Freeman RB, Harper AM, Kamath PS, Wiesner RH: MELD score as a predictor of pretransplant and posttransplant survival in OPTN/UNOS status 1 patients. Hepatology 2004, 39:764-769.

24. Narayanan Menon KV, Nyberg SL, Harmsen WS, DeSouza NF, Rosen CB, Krom RA, Wiesner RH: MELD and other factors associated with survival after liver transplantation. Am J Transplant 2004, 4:819-825.

25. Kogure T, Ueno Y, Kawagishi N, Kanno N, Yamagiwa Y, Fukushima K, Satomi S, Shimosegawa T: The model for end-stage liver disease score is useful for predicting economic outcomes in adult cases of living donor liver transplantation. J Gastroenterol 2006, 41:1005-1010.

26. Chang T-J: Prognostic factors of postoperative ARF. Dialysis \& Transplatation 1999, 29:114-123.

27. Faenza S, Santoro A, Mancini E, Pareschi S, Siniscalchi A, Zanzani C, Pinna $A D$ : Acute renal failure requiring renal replacement therapy after orthotopic liver transplantation. Transplant Proc 2006, 38:1141-1142.

28. Fraley DS, Burr R, Bernardini J, Angus D, Kramer DJ, Johnson JP: Impact of acute renal failure on mortality in end-stage liver disease with or without transplantation. Kidney Int 1998, 54:518-524.

29. Uchino S, Kellum JA, Bellomo R, Doig GS, Morimatsu H, Morgera S, Schetz M, Tan I, Bouman C, Macedo E, Gibney N, Tolwani A, Ronco C: Acute renal failure in critically ill patients: a multinational, multicenter study. JAMA 2005, 294:813-818.

30. Cabezuelo JB, Ramirez P, Acosta F, Sanchez Bueno F, Robles R, Pons JA, Miras M, Munitiz V, Fernandez JA, Lujan J, Rodriguez JM, Bru M, Berenguer $\mathrm{JJ}$, Parrilla P: Prognostic factors of early acute renal failure in liver transplantation. Transplant Proc 2002, 34:254-255.

31. de Mendonca A, Vincent JL, Suter PM, Moreno R, Dearden NM, Antonelli $\mathrm{M}$, Takala J, Sprung C, Cantraine F: Acute renal failure in the ICU: risk factors and outcome evaluated by the SOFA score. Intensive Care Med 2000, 26:915-921.

32. Faenza S, Bernardi E, Cimatti M, Dante A, Mancini E, Miklosova Z, Piraccini E, Pierucci E, Riganello I, Spedicato S, Zanoni A, Santoro A: Acute renal failure after liver transplantation in MELD era. Transplant Proc 2007, 39:1945-1946.

33. Biancofiore $\mathrm{G}$, Davis CL: Renal dysfunction in the perioperative liver transplant period. Curr Opin Organ Transplant 2008, 13:291-297.

34. Gonwa TA, McBride MA, Anderson K, Mai ML, Wadei H, Ahsan N: Continued influence of preoperative renal function on outcome of orthotopic liver transplant (OLTX) in the US: where will MELD lead us? Am J Transplant 2006, 6:2651-2659. 
35. Planinsic RM, Lebowitz JJ: Renal failure in end-stage liver disease and liver transplantation. Int Anesthesiol Clin 2006, 44:35-49.

36. Cabezuelo JB, Ramirez P, Rios A, Acosta F, Torres D, Sansano T, Pons JA, Bru M, Montoya M, Bueno FS, Robles R, Parrilla P: Risk factors of acute renal failure after liver transplantation. Kidney Int 2006, 69:1073-1080.

37. Shaw BW Jr, Martin DJ, Marquez JM, Kang YG, Bugbee AC Jr, Iwatsuki S, Griffith BP, Hardesty RL, Bahnson HT, Starzl TE: Venous bypass in clinical liver transplantation. Ann Surg 1984, 200:524-534.

38. Shaw BW Jr, Martin DJ, Marquez JM, Kang YG, Bugbee AC Jr, Iwatsuki S, Griffith BP, Hardesty RL, Bahnson HT, Starzl TE: Advantages of venous bypass during orthotopic transplantation of the liver. Semin Liver Dis 1985, 5:344-348

39. Gallardo M, Gutierrez M, Pérez G, Balsera E, Ortega J, Garcia G: Risk factors for renal dysfunction in the postoperative course of liver transplant. Liver Transp/ 2004, 10:1379-1385.

40. Ruiz R, Barri YM, Jennings LW, Chinnakotla S, Goldstein RM, Levy MF, McKenna GJ, Randall HB, Sanchez EQ, Klintmalm GB: Hepatorenal syndrome: a proposal for kidney after liver transplantation (KALT). Liver Transpl 2007, 13:838-843.

41. Weismuller TJ, Prokein J, Becker T, Barg-Hock H, Klempnauer J, Manns MP, Strassburg CP: Prediction of survival after liver transplantation by pretransplant parameters. Scand J Gastroenterol 2008, 43:736-746.

42. Ruiz R, Kunitake H, Wilkinson AH, Danovitch GM, Farmer DG, Ghobrial RM, Yersiz H, Hiatt JR, Busuttil RW: Long-term analysis of combined liver and kidney transplantation at a single center. Arch Surg 2006, 141:735-741. discussion 741-732

43. Lo CM, Fan ST, Liu CL, Yong BH, Wong Y, Lau GK, Lai CL, Ng IO, Wong J: Lessons learned from one hundred right lobe living donor liver transplants. Ann Surg 2004, 240:151-158.

44. Marik PE, Wood K, Starzl TE: The course of type 1 hepato-renal syndrome post liver transplantation. Nephrol Dial Transplant 2006, 21:478-482.

45. Cherry T, Steciuk M, Reddy VV, Marques MB: Transfusion-related acute lung injury: past, present, and future. Am J Clin Pathol 2008, 129:287-297.

46. Klein HG, Spahn DR, Carson JL: Red blood cell transfusion in clinical practice. Lancet 2007, 370:415-426.

47. Tinmouth A, Fergusson D, Yee IC, Hebert PC: Clinical consequences of red cell storage in the critically ill. Transfusion 2006, 46:2014-2027.

48. de Rougemont O, Dutkowski P, Weber M, Clavien P-A: Abdominal drains in liver transplantation: useful tool or useless dogma? A match casecontrol study. Liver Transp/ 2009, 15:96-101.

49. Massicotte L, Lenis S, Thibeault L, Sassine MP, Seal RF, Roy A: Effect of low central venous pressure and phlebotomy on blood product transfusion requirements during liver transplantations. Liver Transp/ 2006, 12:117-123.

50. Nardo B, Bertelli R, Montalti R, Beltempo P, Puviani L, Pacile V, Cavallari A: Red blood cell transfusion in liver transplantation: a case-control study. Transplant Proc 2005, 37:4389-4392.

51. Rueggeberg A, Boehm S, Napieralski F, Mueller AR, Neuhaus P, Falke KJ, Gerlach H: Development of a risk stratification model for predicting acute renal failure in orthotopic liver transplantation recipients. Anaesthesia 2008, 63:1174-1180.

52. Smith JO, Shiffman ML, Behnke M, Stravitz RT, Luketic VA, Sanyal AJ, Heuman DM, Fisher RA, Cotterell AH, Maluf DG, Posner MP, Sterling RK: Incidence of prolonged length of stay after orthotopic liver transplantation and its influence on outcomes. Liver Transp/2009, 15:273-279

53. McCormack L, Petrowsky H, Jochum W, Mullhaupt B, Weber M, Clavien PA: Use of severely steatotic grafts in liver transplantation: a matched casecontrol study. Ann Surg 2007, 246:940-946. discussion 946-948

54. Tector AJ, Mangus RS, Chestovich P, Vianna R, Fridell JA, Milgrom ML, Sanders C, Kwo PY: Use of extended criteria livers decreases wait time for liver transplantation without adversely impacting posttransplant survival. Ann Surg 2006, 244:439-450.

55. Candel FJ, Grima E, Matesanz M, Cervera C, Soto G, Almela M, Martinez JA, Navasa M, Cofan F, Ricart MJ, Perez-Villa F, Moreno A: Bacteremia and septic shock after solid-organ transplantation. Transplant Proc 2005, 37:4097-4099.

56. Singh N, Paterson DL, Gayowski T, Wagener MM, Marino IR: Predicting bacteremia and bacteremic mortality in liver transplant recipients. Liver Transp/ 2000, 6:54-61.
57. Angus DC, Wax RS: Epidemiology of sepsis: an update. Crit Care Med 2001, 29:S109-116.

58. Gurusamy KS, Kumar Y, Davidson BR: Systematic review on preventing bacterial sepsis and wound complications in liver transplant patients methods of preventing bacterial sepsis and wound complications for liver transplantation. Cochrane Database Syst Rev 2008:CD006660.

59. Dellinger RP, Carlet JM, Gerlach H, Ramsey G, Levy M: The surviving sepsis guidelines: not another "groundhog day". Crit Care Med 2004, 32:1601-1602

60. Dellinger RP, Levy MM, Carlet JM, Bion J, Parker MM, Jaeschke R, Reinhart K, Angus DC, Brun-Buisson C, Beale R, Calandra T, Dhainaut JF, Gerlach H, Harvey M, Marini JJ, Marshall J, Ranieri M, Ramsay G, Sevransky J, Thompson BT, Townsend S, Vender JS, Zimmerman JL, Vincent JL: Surviving Sepsis Campaign: international guidelines for management of severe sepsis and septic shock: 2008. Intensive Care Med 2008, 34:17-60.

doi: $10.1186 /$ cc9068

Cite this article as: Oberkofler et al., Model of end stage liver disease (MELD) score greater than 23 predicts length of stay in the ICU but not mortality in liver transplant recipients Critical Care 2010, 14:R117

\section{Submit your next manuscript to BioMed Central} and take full advantage of:

- Convenient online submission

- Thorough peer review

- No space constraints or color figure charges

- Immediate publication on acceptance

- Inclusion in PubMed, CAS, Scopus and Google Scholar

- Research which is freely available for redistribution 